\title{
SOSIALISASI MANAJEMEN USAHA PRODUKTIF UNTUK MENINGATKAN PENDAPATAN DAN KESEJAHTERAAN KELUARGA
}

\author{
Nawangsih \\ STIE Widya Gama Lumajang \\ lovinawang@gmail.com
}

\begin{abstract}
ABSTRAK
Kegiatan pengabdian masyarakat yang dilakukan bertujuan untuk memberikan pengetahuan dan gambaran secara lebih spesifik terkait dengan peluang usaha yang bisa dijalankan oleh ibu rumah tangga, melalui beberapa contoh usaha yang memungkinkan untuk dijalankan oleh para ibu rumah tangga yang berada di Desa Karangsari, Kecamatan Sukodono, Kabupaten Lumajang. Metode kegiatan pengabdian masyarakat yang dilakukan terdiri dari beberapa rangkaian kegiatan, antara lain : kegiatan ke 1 yaitu : melakukan melakukaan kesepakatan dengan mitra untuk mencari solusi dari permasalahan yang dihadapi, melalui kegiatan : koordinasi dengan mitra, obervasi cara menjalankan usaha mitra, kegiatan ke 2 yaitu : melaksanakan kegiatan sosialisasi manajemen usaha produktif untuk meningkatkan pendapatan dan kesejahteraan keluarga dan kegiatan ke 3 yaitu : melaksanakan kegiatan serupa secara berkelanjutan sehingga menumbuhkan kerja sama yang baik antara pihak mitra dengan STIE Widya Gama Lumajang. Kegiatan sosialisasi diberikan dengan tujuan agar para ibu rumah tangga, untuk secara kreatif dan inovatif menciptakan peluang usaha baru baik secara mandiri maupun berkelompok, sehingga mereka bisa memperoleh tambahan penghasilan dari usaha yang dijalankan, waktu luang yang ada bisa dimanfaatkan secara maksimal untuk kegiatan yang produktif, menghasilkan dan bermanfaat.
\end{abstract}

Kata kunci : Sosialisasi, usaha produktif, pendapatan, keluarga

\begin{abstract}
Community service activities carried out aim to provide more specific knowledge and images related to business opportunities that can be run by housewives, through several examples of possible businesses to be run by housewives in Karangsari Village, Sukodono District, Lumajang Regency. The method of community service activities carried out consisted of several series of activities, including: 1st activity, namely: carrying out agreements with partners to find solutions to the problems faced, through activities: coordination with partners, observation of how to run a partner business, 2nd activity namely: conduct productive business management socialization activities to increase family income and welfare and the third activity, namely: carrying out similar activities on an ongoing basis so as to foster good cooperation between partners with STIE Widya Gama Lumajang. Socialization activities are provided with the aim that housewives, to creatively and innovatively create new business opportunities both independently and in groups, so that they can obtain additional
\end{abstract}


income from the business carried out, the available leisure time can be maximally utilized for productive activities, produce and be useful.

\section{Keyword : Socialization, productive business, income, family}

\section{PENDAHULUAN}

\section{A. Analisis Situasi}

Manajemen waktu sangat penting dan memegang peranan yang krusial bagi keberhasilan sebuah usaha atau kegiatan yang dilakukan, tidak terkecuali dengan kaum perempuan dalam hal ini ibu rumah tangga. Ibu rumah tangga adalah sebuah profesi yang mulia dan multi tasking. Beragam kegiatan dapat dilakukan seorang ibu rumah tangga di tengah segala kesibukan yang dilakukan. Nilai lebih dari seorang ibu rumah tangga yang lain adalah jika mereka mampu berperan ganda yaitu ibu rumah tangga sekaligus juga menjadi seorang wirausaha dengan cara mengaplikasikan manajemen usaha produktif di tengah kesibukan yang meraka jalani setiap harinya, baik sebagai wanita karier, pengurus POSYANDU, ibu-ibu PKK atau beragam profesi lainnya.

Ibu rumah tangga sekaligus wirausaha sudah mulai marak akhir-akhir ini, ibu rumah tangga mampu memperoleh penghasilan tambahan tanpa harus meninggalkan tugas utamanya sebagai seorang ibu rumah tangga, memanfaatkan waktu dengan melakukan aktifitas positif menjadi alternatif yang menguntungkan sekaligus menjadi sarana yang efektif dalam memanfaatkan waktu agar bernilai guna dan berhasil guna. Perempuan dalam rumah tangga mengerjakan begitu banyak pekerjaan rumah tangga, mulai dari merawat dan memberi makanan bergizi kepada anak dan anggota rumah tangga yang tua/sakit (Darmawan, 2011; Darmawan, 2014), memasak, bersih-bersih dan seterusnya).

Manajemen usaha produktif yang dilakukan oleh ibu rumah tangga dengan cara mengerjakan usaha sampingan sebagai upaya membantu untuk menambah pendapatan dan kesejahteraan keluarga dapat dilakukan di waktu luang mereka sebagai sebuah tindakan yang positif sehingga waktu luang dapat lebih optimal untuk bisa dimanfaatkan.

Manajemen usaha produktif adalah sebuah kegiatan manajemen yang dilakukan dengan maksud dan tujuan untuk melatih kita agar bisa menjadi manusia yang produktif dengan melalui kegiatan usaha yang dilakukan. 
Manajemen usaha produktif dapat dilakukan oleh semua orang yang tertari untuk dapat menciptakan sebuah peluang usaha baru atau mengembangkan usaha yan telah dijalankan sebelumnya agar hasilnya menjadi lebih maksimal, berhasil guna dan berdaya guna sesuai dengan yang diharapkan.

Manajemen usaha produktif secara garis meliputi 3 kegiatan utama yang dilakukan antara lain : 1). Membantu program pemerintah, melalui kegiatan manajemen usaha produktif maka kita secara langsung ikut berkontribusi dalam membantu pemerintah untuk memberdayakan masyarakat misalnya ibu rumah tangga agar lebih mandiri, mampu menciptakan peluang kerja, mendapatkan penghasilan tambahan dengan tidak melupakan kewajiban utama sebagai ibu rumah tangga dan istri, 2).Efisien dan efektif dalam mengelola keuangan keluarga, melalui kegiatan manajemen usaha produktif secara langsung ibu rumah tangga dapat belajar tentang cara mengelola keuangan keluarga secara lebih bijak dan mengelola pendapatan dari usaha sampingan yang dijalankan dan 3). Menciptakan peluang usaha produktif untuk menambah pendapatan keluarga, kegiatan ini dilakukan dengan harapan agar peluang usaha produktif yang diciptakan bukan hanya untuk kepentingan usaha yang dijalankan melainkan dapat memberikan manfaat yang lebih luas lagi yaitu memberikan peluang kerja bagi orang lain.

Manfaat kegiatan manajemen usaha produktif, antara lain adalah : 1).Membuka usaha baru. Membuka usaha baru dapat menjadi pilihan bagi ibu rumah tangga untuk mendapatkan penghasilan tambahan keluarga, yang dapat dilakukan dengan melihat kondisi dan potensi yang ada di sekitar, 2). Merubah hobby menjadi peluang bisnis. Hoby adalah melakukan aktifitas atau kegiatan yang kita sukai dan kita lakukan secara rutin. Hoby yang awalnya hanya sekedar coba-coba akan menjadi lebih produktif, jika kita kembangkan lagi menjadi peluang usaha dengan prospek yang bagus dan 3). Membantu kegiatan perekonomian keluarga. Usaha sampingan yang dilakukan oleh ibu rumah tangga dapat menambah pendapatan keluarga karena mendapatkan tambahan penghasilan lain sehingga pemasukan akan enjadi lebih besar, aktifitas usaha akan berjalan dengan baik jika kita mampu mengelola usaha yang dijalankan secara profesional

Pengembangan ekonomi rumah tangga (household economic) dan peran gender (role of gender) dalam perekonomian bukanlah wacana baru lagi saat sekarang 
(Diniari, 2000; Astiti, 2013). Dari sisi sumber pendapatan rumah tangga, peran perempuan memiliki kontribusi $31 \%$ terhadap pendapatan total rumah tangga (Astiti, Darmawan et,all 2017).

Melihat kontribusi tersebut maka amat layak untuk dilakukan perencanaan dan pendampingan usaha dari sisi manajemen, mengingat beberapa permasalahan yang dihadapi oleh ibu rumah tangga adalah ketika memutuskan melakukan atau membuka usaha mereka belum memahami tentang persiapan dan tindakan manajemen usaha yang harus dilakukan untuk dapat melaksanakan sebuah usaha.

\section{B. Permasalahan Mitra}

Berdasarkan informasi awal yang diberikan oleh mitra terkait dengan situasi dan kondisi yang terjadi maka identifikasi awal terhadap masalah yang dihadapi mitra, antara lain : terbatasnya pengetahuan dan informasi ibu rumah tangga terhadap kegiatan manajemen usaha dan belum memahami strategi atau tips yang tepat yang bisa digunakan untuk membuka usaha baru yang potensial dan layak untuk dikembangkan

\section{Solusi yang Ditawarkan}

Solusi efektif yang bisa ditawarkan untuk membantu mengatasi permasalahan yang dihadapi oleh mitra adalah sebagai berikut : memberikan sosialisasi untuk memberikan gambaran pengetahuan dan informasi kepada ibu rumah tangga tentang manajemen usaha produktif berkaitan dengan strategi atau tips membuka usaha baru yang potensial dan layak untuk dikembangkan untuk meningkatkan pendapatan dan kesejahteraan keluarga

\section{Target Luaran}

Kegiatan pengadian kepada masyarakat yang dilakukan ini diharapkan dapat menghasilkan target sesuai dengan harapan dari mitra yaitu : mendapatkan pengetahuan pengetahuan dan informasi ibu rumah tangga tentang manajemen usaha produktif secara lebih jelas dan lengkap dan mitra mampu mengaplikasikan kegiatan manajemen usaha produktif dalam kegiatan usaha yang akan dan telah dilaksanakan sebelumnya, agar hasil yang diperoleh menjadi lebih maksimal. 


\section{METODE PELAKSANAAN}

Langkah efektif yang digunakan pada kegiatan pengabdian kepada masyarakat dilakukan untuk menjawab permasalahan yang dihadapi oleh mitra sebagai berikut :

1. Metode pertama, melakukaan kesepakatan dengan mitra untuk mencari solusi dari permasalahan yang dihadapi antara lain : melaksanakan koordinasi dengan mitra untuk mengetahui berbagai jenis usaha yang dilakukan oleh ibu rumah tangga di Desa Karangsari dan melaksanakan observasi / pengamatan tentang cara menjalankan usaha yang dilakukan oleh mitra

2. Metode kedua, melaksanakan kegiatan sosialisasi manajemen usaha produktif untuk meningkatkan pendapatan dan kesejahteraan keluarga

3. Metode ke tiga, melaksanakan kegiatan serupa secara berkelanjutan sehingga menumbuhkan kerja sama yang baik antara pihak mitra dengan STIE Widya Gama Lumajang.

\section{HASIL YANG DICAPAI}

\section{Hasil Kesepakatan Dengan Mitra}

Berdasarkan hasil kesepakatan dengan mitra untuk mencari solusi dari permasalahan yang dihadapi, maka tindakan yang dilakukan antara lain :

a. Melaksanakan koordinasi dengan mitra untuk mengetahui berbagai jenis usaha yang dilakukan oleh ibu rumah tangga di Desa Karangsari

Kegiatan koordinasi dilakukan untuk mengetahui jenis usaha yang selama ini dijalankan oleh ibu rumah tangga yang ada di Desa Karangsari, hasil sementara yang diperoleh di lapangan menunjukkan bahwa sebagian besar bidang usaha yang dijalankan adalah sebagai penjual toko kelontong dan makanan atau snack anak kecil dengan memanfaatkan toko atau rumah sebagai lokasi usaha sedangkan bentuk kegiatan keseharian yang biasanya dilakukan oleh ibu rumah tangga apabila tidak memiliki usaha sampingan baik memiliki toko atau bekerja di luar rumah, waktu luang setelah mereka menyelesaikan pekerjaan rumah tangga, dimanfaatkan hanya untuk berkumpul dengan tetangga, sehingga banyak waktu luang yang akhirnya 
terbuang percuma untuk hal-hal yang kurang produktif, akan lebih baik jika kondisi tersebut bisa dimanfaatkan untuk hal yang positif.

b. Melaksanakan observasi / pengamatan tentang cara menjalankan usaha yang dilakukan oleh mitra

Berdasarkan hasil kegiatan observasi /pengamatan di lapangan diketahu bahwa yang menjadi mitra usaha sebagian besar adalah ibu rumah tangga yang memiliki usaha sampingan sebagai pedagang makan/snack untuk anak-anak, kegiatan usaha yang dilaksanakan dengan sederhana sekali, baik dari segi dari lokasi usaha, penataan produk dan produk yang dijual. Produk yang dijual oleh mitra sebagian besar dalam bentuk makanan dan minuman instan, yang memang disukai anak-anak, selain karena mudah diperoleh, harga lebih murah dan juga tampilan produk dan warna makanan lebih cerah dan menarik, akan tetapi sebetulnya produk makanan atau minuman tersebut, kurang aman untuk dikonsumsi apalagi untuk anak anak yang masih dalam tahap pertumbuhan, yang membutuhkan makanan yang bergizi dan sehat, sementara produk yang dijual banyak yang dalam bentuk instan sehingga tidak sehat, karena dikhawatirkan mengandung zat berbahaya bagi tubuh apabila dikonsumsi secara terus-menerus, adanya sosialisasi diharapkan para ibu rumah tangga mendapatkan pengetahuan dan informasi usaha yang lebih baik yang bisa mereka laksanakan.

\section{Hasil Pelaksanaan Kegiatan Sosialisasi}

Melaksanakan kegiatan sosialisasi manajemen usaha produktif untuk meningkatkan pendapatan dan kesejahteraan keluarga, untuk menambah pengetahuan dan informasi serta gagasan baru terkait kegiatan manajemen usaha. Bentuk kegiatan sosialisasi yang diberikan seperti tampak pada gambar di bawah ini : 

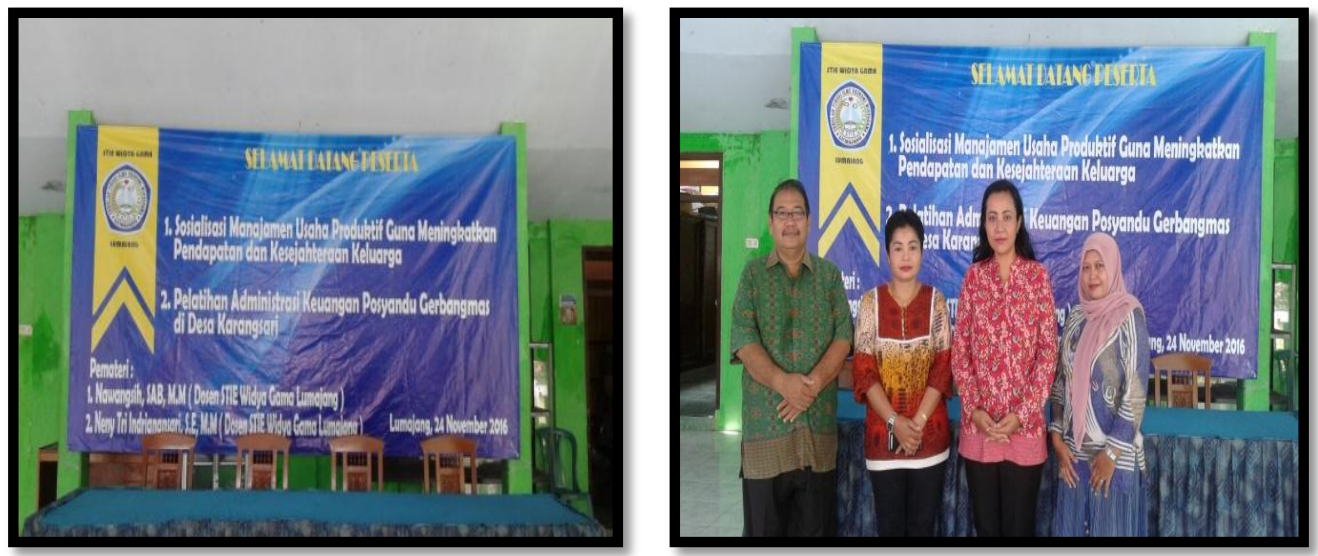

Gambar 1. Pemateri Dengan Perangkat Desa Karangsari

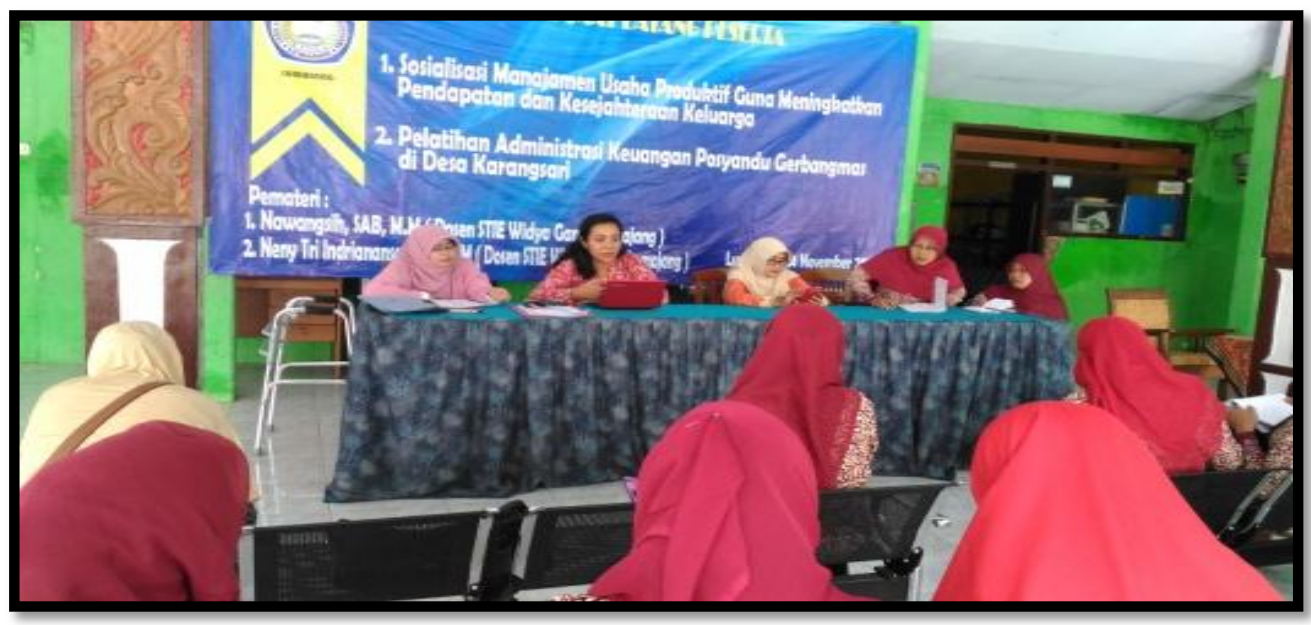

Gambar 2. Pelaksanaan Kegiatan Sosialisasi

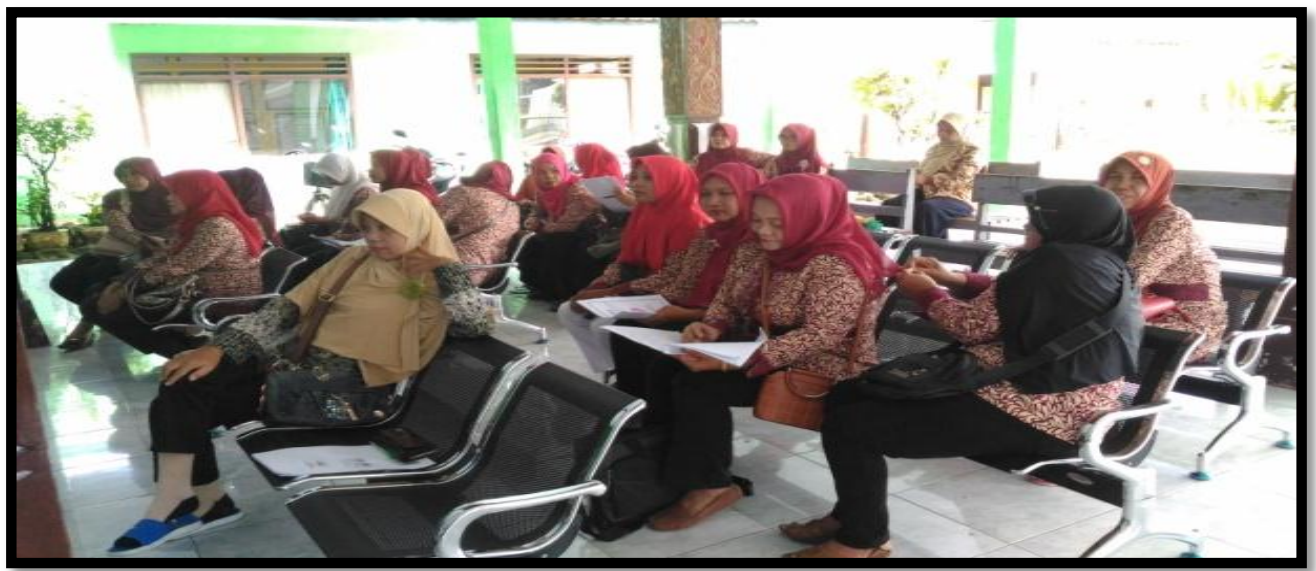

Gambar 3. Peserta Kegiatan Sosialisasi 


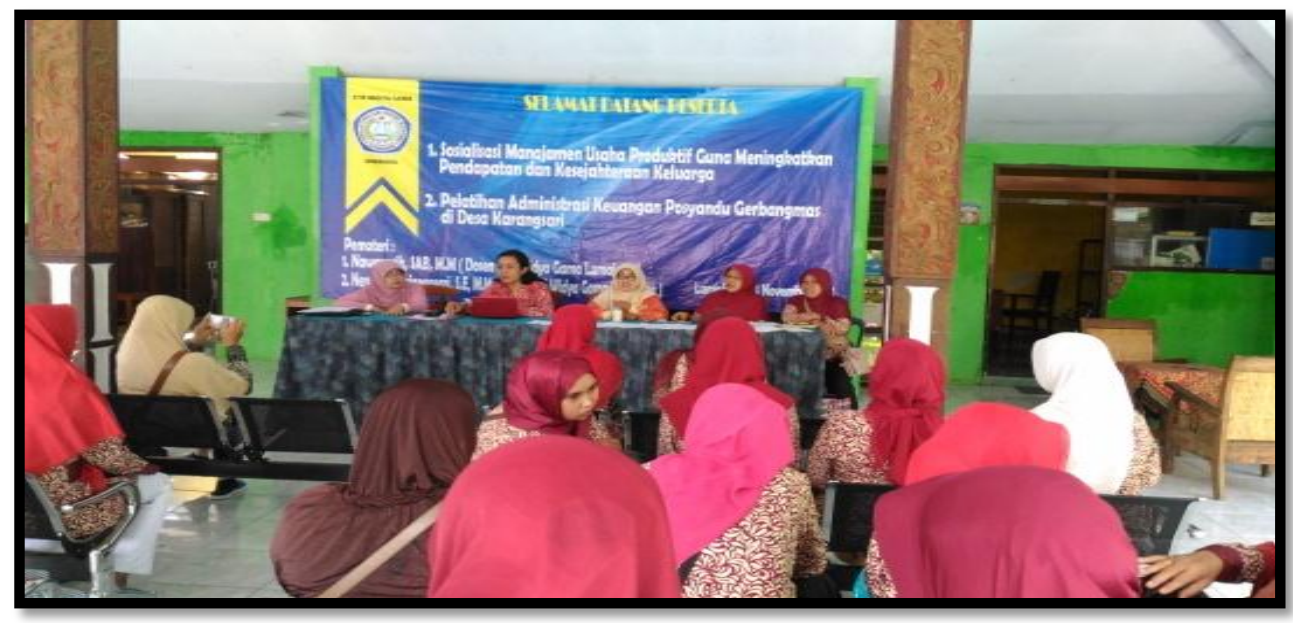

Gambar 4. Sesi Tanya Jawab Dengan Peserta Sosialisasi

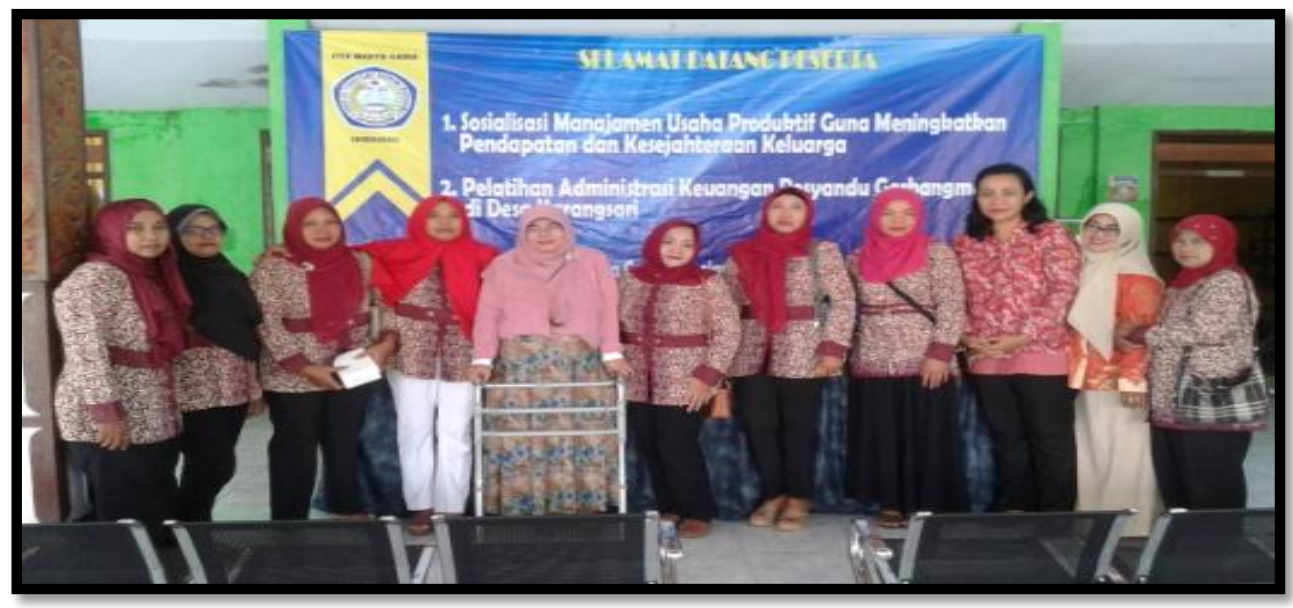

\section{Gambar 5. Dokumentasi Dengan Peserta Sosialisasi}

\section{Hasil Setelah Pelaksanaan Kegiatan}

Setelah kegiatan sosialisasi selesai dilaksanakan diharapkan akan terjalin kerja sama yang baik dan berkelanjutan antara pihak mitra dengan STIE Widya Gama Lumajang. Melalui kerja sama diharapkan usaha yang dijalankan oleh mitra dalam hal ini ibu rumah tangga, bisa lebih maju dan berkembang.

\section{KESIMPULAN}

Program pengabdian masyarakat yang dilaksanakan dalam bentuk kegiatan sosialisasi berjalan dengan baik dan lancar, tanpa ada kendala. Kegiatan 
sosialisasi yang diberikan diharapkan mampu memberikan ide greatif dan gagasan baru lagi yang lebih menarik bagi ibu rumah tangga, sehingga usaha yang dijalankan bisa lebih variatif, lebih maju dan berkembang. Akan tumbuh wirausaha baru lagi dengan bidang usaha yang lebih beragam yang bisa diciptakan oleh ibu rumah tangga tersebut.

\section{SARAN}

Berdasarkan hasil kegiatan yang telah dilaksanakan, maka dapat diajukan beberapa saran, sebagai berikut :

1. Secara kontinyu dan berkelanjutan kegiatan semacam ini dilaksanakan, sehingga dapat memperluas pengetahuan serta peluang usaha produktif yang bisa diciptakan

2. Keterbatasan pengetahuan yang dimiliki membuat usaha yang dilaksanakan belum bisa maksimal, sehingga kegiatan sosialisasi sekaligus memberikan strategi atau tips terkait tentang kegiatan manajemen usaha yang dijalankan agar berhasil

3. Selain kegiatan manajemen usaha, masih banyak peluang pengabdian masyarakat lainnya yang bisa dikembangkan misalnya melalui kegiatan pelatihan, studi banding dan inovasi produk

\section{DAFTAR PUSTAKA}

Astiti, N.W.S. 2013. Ketimpangan Gender dalam Pengelolaan Desa Abang, Kecamatan Marga, Tabanan Bali. Disertasi Tidak Dipublikasi, Universitas Udayana.

Darmawan, D.P. 2011. Ketahanan Pangan Rumah Tangga dalam Konteks Pertanian Berkelanjutan. Denpasar: Udayana University Press.

Darmawan, D.P. 2014. Strategi pembangunan ketahanan pangan dan daya tahan ekonomi masyarakat miskin di perdesaan Bali. Makalah dipresentasikan pada Seminar Strategi Implementasi Program Bali Mandara Jilid II: Harapan dan Kendala di Era Otonomi Daerah, diselenggarakan atas kerjasama Universitas Udayana dan Pemprov Bali, di Gedung Wiswasaba, Kantor Gubernur Bali, Denpasar, 25 September 2014.

Diniari F.S. 2000. Perempuan dan Pekerjaan. S.V. Bemmelen, Atashendartini H. Lugina Setyawati (Eds.), dalam Benih Bertumbuh, Kumpulan Karangan 
untuk T.Omas Ihroni. Panitia Peringatan Ultah Ibu Ihroni ke 70 tahun, Bekerjasama dengan Kedutaan Besar Belanda

Ni Wayan Sri Astiti1), Dwi Putra Darmawan2), I Dewa Gede Raka Sarjana3), Implementasi Model Pemberdayaan Perempuan Berbasis Pengembangan Industri Rumah Tangga Spesifik Lokal Di Kabupaten Karangasem, Provinsi Bali. Jurnal Manajemen Agribisnis Vol. 5, No. 1, Mei 2017 ISSN: 2355 0759 